\title{
QUEEN'S
UNIVERSITY
BELFAST
}

\section{Gender and Politics in Northern Ireland: the representation gap revisited}

Galligan, Y. (2013). Gender and Politics in Northern Ireland: the representation gap revisited. Irish Political Studies, 28(3), 413-433. https://doi.org/10.1080/07907184.2013.826193

Published in:

Irish Political Studies

Document Version:

Peer reviewed version

Queen's University Belfast - Research Portal:

Link to publication record in Queen's University Belfast Research Portal

\section{Publisher rights}

Copyright 2013 Political Studies Association of Ireland.

This is an Accepted Manuscript of an article published by Taylor \& Francis in Irish Political Studies on 10th September 2013, available online: http://wwww.tandfonline.com/10.1080/07907184.2013.826193.

\section{General rights}

Copyright for the publications made accessible via the Queen's University Belfast Research Portal is retained by the author(s) and / or other copyright owners and it is a condition of accessing these publications that users recognise and abide by the legal requirements associated with these rights.

Take down policy

The Research Portal is Queen's institutional repository that provides access to Queen's research output. Every effort has been made to ensure that content in the Research Portal does not infringe any person's rights, or applicable UK laws. If you discover content in the Research Portal that you believe breaches copyright or violates any law, please contact openaccess@qub.ac.uk. 
Gender and Politics in Northern Ireland: the representation gap revisited.

\section{YVONNE GALLIGAN}

School of Politics, International Studies and Philosophy, Queen's University Belfast, Belfast, Northern Ireland.

ABSTRACT This article examines the nature of gender politics since the 1998 Good Friday-Belfast Agreement. Taking gender justice as a normative democratic framework, the article argues that despite the promise of women's equal participation in public and political life written into the Agreement, parties have delivered varied responses to integrating women, women's interests and perspectives into politics and policy platforms. This contrasts with general patterns supporting women's increased participation in social and political life. The article discusses women's descriptive and substantive representation through electoral outcomes and party manifestos, using the demands of successive women's manifestos as a benchmark. It concludes that while parties have given less recognition and inclusion to women than one might have expected in a new political context, the push for democratic accountability will ensure that gender politics will continue to have a place on the political agenda for some time to come.

Keywords: Northern Ireland, descriptive representation, substantive representation, candidate selection, political parties

\section{Introduction}

When the Good Friday/Belfast Agreement was signed on 10 April 1998 it heralded the prospect of a new politics of peace, inclusion and mutual respect between the two ethno-national cultural and political traditions in Northern Ireland. That hope was given public expression six week later, when 71 per cent of voters endorsed the Agreement as the basis for power-sharing politics (Hayes and McAllister, 2013: 125). In addition to securing a power-sharing institutional apparatus, the Agreement affirmed a series of fundamental rights, including the right of women to 'full and equal political participation' (Fearon, 2000: 155). For the first time in its long and troubled history, women's right to political inclusion were formally recognised in Northern Ireland. Formal recognition, however, is but one step on the way to full absorption of women and women's interests in political affairs, and this article charts the changing representation gap, descriptive and 1

Correspondence Address: Yvonne Galligan, School of Politics, International Studies and Philosophy, Queen's University Belfast, University Road, Belfast BT7 1NN, Northern Ireland. Email: y.galligan@qub.ac.uk. 
substantive, in Northern Ireland's gender politics. It draws on empirically-based evaluation of gender justice to do so. Elaborated in section one, these are: inclusion, transparency, accountability and recognition. The growing empowerment of women in Northern Ireland is charted in section two through their participation in the economy and public affairs, making their low political representation appear out of kilter with these patterns. Section three explores women's political representation in more detail, seeking to account for their inability to access politics. Close attention is paid to party policies on women since 1998 in section four, which analyses party manifestos to reveal the degree to which parties have been prepared to go beyond formal rhetoric and towards a more substantive policy of inclusion. It concludes by evaluating prospects for change in light of the criteria initially outlined, suggesting that issues of gender justice in democratic politics are likely to remain on the political agenda into the future.

\section{Framing gender politics in Northern Ireland}

The Good Friday-Belfast Agreement, and its subsequent modifications in the St. Andrews (2006) and Hillsborough (2010) negotiations provided for the mutual accommodation of ethno-national interests through mechanisms such as cross-community power-sharing and minority veto rights (O'Leary, 1999: 1630). It framed gender equality and other civic and social rights as a subsidiary to national identity, bearing out the long-held observation that peace settlements perpetuate gender inequality in a post-conflict context (Murtagh, 2008: 26). As Hayes and McAllister (2013: 124) observe, 'not only are many peace agreements negotiated exclusively by men, but they also reinforce male privilege at the expense of gender equality.'

It is helpful, in seeking to evaluate the extent to which Northern Ireland's peace politics has to exclude women and women's interests, to draw on the empirical development of gender justice criteria that have recently been employed to evaluate the quality of democratic processes more generally (Clavero and Galligan 2010, Galligan 2012). Deriving from the notion that democracy 
ought to deliver justice for and between women and men (Fraser 1998), the insights on gender equality as a group right (Moller-Okin 1999), and the importance of inclusion as a democratic practice (Young 2002), the principles enable the researcher to identify the extent to which gender equality goes beyond being a rhetorical commitment to one that is embedded in institutional policies and organisational procedures. In the practice of this embedding, it is expected that shifts in cultural attitudes and behaviours will occur, leading to the greater descriptive and substantive representation of women and women's interests.

These empirically-focused principles are four-fold: inclusion, transparency, accountability, and recognition (Galligan and Clavero 2008). Inclusion directs attention to the participation of women as equals with men in institutional decision-making forums, and to supporting organisational practices to that end (eg sex quotas for decision-making positions). It also refers to the substantive inclusion of women's interests in policy platforms and agendas. Transparency implies that the rules of institutional processes - such as candidate selection, elections to party executive positions, or policy formulation - are known and accessible to all members, permitting them to participate in these processes. It also encompasses open political practices rather than elite-determined politics. Accountability captures the requirement for leaders (women and men) to be answerable to women members, and the party membership more generally, for their actions in redressing sex-based discriminations, in both internal practices and in policy concerns. It requires parties to be accountable to the interests of female supporters. It also shades into the final criteria, recognition, which calls on democratic institutions to be substantially responsive to, as well as formally recognising, the existence of historically-based discriminations against women. Recognition requires democratic institutions such as parties to treat with seriousness those articulating these substantive concerns, as well as the issues themselves (Galligan and Clavero 2008).

Overlapping in practice, these normatively-derived criteria provide yardsticks for assessing the extent and quality of the gender equality culture fostered within political institutions, including

Correspondence Address: Yvonne Galligan, School of Politics, International Studies and Philosophy, Queen's University Belfast, University Road, Belfast BT7 1NN, Northern Ireland. Email: y.galligan@qub.ac.uk. 
parties. Accordingly, the evidence from fifteen years of peaceful politics in Northern Ireland will be discussed in their light in the concluding section of this article. First, though, the progress of gender equality in the public sphere will be outlined as a context for the political discussions to come.

\section{Equal Participation: Progress since 1998}

That there is recognition of gender equality in political and public life in the Agreement is attributed to the influence of the cross-community Northern Ireland Women's Coalition (NIWC) during the peace talks (Cowell-Meyers, 2011: 412; Side, 2009:69; Ward, 2004: 4). This achievement should not be underestimated, for, as O'Keeffe (2012) and Potter (2012) compellingly show, the structural recognition of ethno-national identity pervading political and public discourse in Northern Ireland suppresses the articulation of other differences, including gender roles and the subject positioning of women (Coakley, 2012:46). Fifteen years on from this significant moment in the politics of Northern Ireland, the promise of women's full and equal political participation is largely unfulfilled. In terms of descriptive representation, and unlike other devolved legislatures in the UK, men hold a supermajority ( 81.5 per cent) of seats in Northern Ireland's Legislative Assembly.

\section{FIGURE 1 ABOUT HERE}

The gendered patterns of representational politics illustrated in Figure 1 have continued over the one and a half decades since the devolved institutions were brought into being since 1998. In Northern Ireland, women's representation has marginally increased from a tokenistic 13 per cent to one verging on that of a small minority of almost 20 per cent. In contrast, the other devolved legislatures have maintained a relatively stable representation of at least one-third female seatholding, reflecting the pattern of women's average representation. However, as the figures show, women's hold on political office in the devolved institutions is not necessarily stable or enduring, and constant attention needs to be paid to increasing women's descriptive representation (Kenny 2013).

4

Correspondence Address: Yvonne Galligan, School of Politics, International Studies and Philosophy, Queen's University Belfast, University Road, Belfast BT7 1NN, Northern Ireland. Email: y.galligan@qub.ac.uk. 
In Northern Ireland, the persistence in low levels of female representation is part of an historical pattern. Only 16 women were elected to the various iterations of Northern Ireland's legislative bodies between its foundation as a political entity in 1921 to 1986 . Of these, only four were nonunionist. ${ }^{1}$. Some progress has been made since 1989 , when women's share of local council seats was a tokenist 9 per cent. The proportion of women councillors has since grown to a moderate 24 per cent (Figure 2), though it still lags behind the 32 per cent average representation of women in local councils in the EU 27-member states (European Commission, 2013).

\section{FIGURE 2 ABOUT HERE}

Women have also made modest inroads into positions of administrative leadership of councils: by 2011, five women (19 per cent) were among the chief executives of the 26 councils, due in part to the efforts of the Local Government Staff Commission in increasing women's leadership capacities as councillors and administrators (Hinds, 2012: 100-101). However, this modest progress in women gaining elected and official positions is not certain to continue. Following a protracted review of public administration, a major reform of local government is scheduled to reduce the number of councils from 26 to 11 by 1 April 2015, accompanied by greater powers for local authorities (Cave, 2012). The number of councillors will decrease from 582 to about 460, with elections to 'shadow' councils to take place in 2014 in preparation for full transition to the new arrangements within one year. By mid-2013, no consideration had been given to the consequences of these reforms for women's local council representation, despite the issue being signalled by feminist experts (Hinds and Gray, 2005; WRDA, 2005: 6). This illustrates the difficulty of inserting gender equality in the creation of modern governance structures. It is thus not surprising to find that although women constituted almost one-quarter of elected councillors in 2013, their representation on the important preparatory transition committees was only 15 per cent.

\footnotetext{
${ }^{1}$ Lilian Calvert (Ind) 1929-33; Eileen Hickey (Ind) 1949-58; Sheelagh Murnihan (Liberal) 1961-69 and Mary McSorley (SDLP) 1982-86.
}

Correspondence Address: Yvonne Galligan, School of Politics, International Studies and Philosophy, Queen's University Belfast, University Road, Belfast BT7 1NN, Northern Ireland. Email: y.galligan@qub.ac.uk. 
A review of women's presence in sites of influence other than politics since 1998 indicates that while women have been gradually taking on leadership roles in economic, professional and public life in Northern Ireland, the top positions continue to elude them. The judiciary is a case in point. In 2003, women comprised 35 per cent of judicial office-holders and 7 per cent of senior barristers (Feenan, 2005:96). Ten years later, although the senior judiciary remained male-dominated, women's share of judicial positions had increased to 43 per cent and their representation in the legal profession stood at 38 per cent (NIJAC, 2013). Positive though this progress is, the figures mask an uneven distribution of judicial power: women comprised only 24 per cent of county and district magistrates' court judge (and deputy judge) positions and were more strongly represented in the lower courts (44 per cent), non-legal tribunals (44 per cent) and as lay magistrates (55 per cent) (NISRA, 2012).

Another touchstone of women's progress into positions of influence is their representation among the senior civil service. Here too, women have made steady progress over a decade: in 2001, 32 women (13 per cent) were employed at the senior Grade 5 and above, by 2010 this had increased to 59 (29 per cent). Women held 12 (25 per cent) of the top 48 positions, Grade 3 and above in 2010, rising from 9.5 per cent in 2001 (DFP, 2012). However, as in the judiciary, there were no women among the 12 permanent secretaries in 2013 , and in both fields there is an obvious 'glass ceiling' in place that will take some further time to address.

Northern Ireland is heavily governed, with 88 public bodies and about 1,400 public appointment positions within the remit of the Northern Ireland Executive in 2012 (OFMDFM, 2012:4). There has been a reduction in the number of boards and positions since 1997, when Northern Ireland had 145 public bodies with a total of 2,948 members (Northern Ireland Assembly, 2002:3). Then, as now, women comprised around one-third of board members, 35 per cent in 1996 and 34 per cent in 2010. Over this time, women have held about one-quarter of chairperson positions, ranging from 42 of 211 posts (26 per cent) in 2000 to holding 22 per cent of chairperson positions in 2010 (Northern Queen's University Belfast, University Road, Belfast BT7 1NN, Northern Ireland. Email: y.galligan@qub.ac.uk. 
Ireland Assembly, 2002:9; OFMDFM, 2010:14). This is an area where progress towards gender equality has stalled in the post-Agreement period.

In a divided society emerging from prolonged conflict, the enforcement of the rule of law through policing becomes a highly sensitive matter, and the agency charged with enforcing law and order is required to be acceptable to former protagonists and their communities if the peace process is to be sustained. Following the introduction of a new policing service recommended by the Patton Report, The Police Service of Northern Ireland (PSNI), formed in November 2001, introduced a 50:50 Catholic-Protestant recruitment quota ${ }^{2}$, but did not extend this to a sex quota. Yet, the religious quota had a positive effect over time on women's recruitment, if not by design. In 2002, 13 per cent of regular police officers were female; this had doubled to 27 per cent by 2009 , and compared favourably with women's presence in the police forces of England and Wales (25 per cent), Scotland (23 per cent), New Zealand (18 per cent) and a post-conflict country, South Africa (24 per cent) (Prenzler and Sinclair, 2013). Women are also making inroads into PSNI senior positions, comprising 22 per cent of Superintendents in 2013 compared with 5 per cent in 2004. This progress has come about through the opening of access to employment in this area as a consequence of the affirmative recruitment policy, and to implementation of successive gender equality plans, as provided for in the Police (NI) Act 2000.

The continued rise of women to prominent positions in the public life of Northern Ireland reflects the changing workforce composition over two decades. In 1995, when the prospect of peace began to take hold, 57 per cent of working-age women were in employment, compared with 69 per cent of men. By 2013, this 12-point employment gap had narrowed: 63 per cent of working-age women were employed, as were 70 per cent of men (see Figure 4).

\section{FIGURE 3 ABOUT HERE}

\footnotetext{
2 Permitted under Section 46(1) of the Police (NI) Act 2000

Correspondence Address: Yvonne Galligan, School of Politics, International Studies and Philosophy, Queen's University Belfast, University Road, Belfast BT7 1NN, Northern Ireland. Email: y.galligan@qub.ac.uk.
} 
In general, then, women have been taking their place in public and economic life in Northern Ireland since 1998. Professional women are gradually making inroads in their sectors, and more women are in paid employment. However, the score-card is not a fully positive one: women's opportunities for public governance have stagnated, the recession has impacted severely on economically vulnerable women, and with the move to wean the Northern Ireland economy off its dependence on public sector employment, women's earnings are projected to decrease (WRDA and Hinds, 2011, OFMDFM, 2010a). It is clear also that there is a 'glass ceiling' effect in terms of women's advancement to senior positions of influence. This inability to break into the top echelons of public power is reflected also in women's relative absence from Assembly politics, and discussed in more detail in the next section

\section{Politics: A 'Cold House’ for Women in Northern Ireland}

The 1998 Belfast/Good Friday Agreement, which provided a constitutional framework for the introduction of peaceful and inclusive democratic politics, signalled a commitment to:

the mutual respect, the civil rights and the religious liberties of everyone in the community. Against the background of the recent history of communal conflict, the parties affirm in particular....the right of women to full and equal political participation.

Indeed, this statement is in line with Article 7 of the binding United Nations Convention on the Elimination of all forms of Discrimination Against Women (CEDAW) guaranteeing women's political and public rights, including voting, election, contribution to public policy formation and civil society participation. $^{3}$ It is also consonant with the provisions of the United Nations Security Council Resolution 1325 reaffirming the important role and contribution of women in building peace and security. ${ }^{4}$ Notwithstanding these international commitments to women's public and political participation, parties in Northern Ireland have been markedly reluctant to give the provision substantive effect (Side, 2009: 81-82). The practice of holding dual, or even triple, mandates is slow

\footnotetext{
${ }^{3}$ Convention on the Elimination of All forms of Discrimination Against Women (CEDAW), 1975, available at http://www.un.org/womenwatch/daw/cedaw/cedaw.htm (last accessed 30 March 2012)

4 Landmark Resolution by the UN Security Council on women, peace and security, available at http://www.un.org/womenwatch/osagi/wps/ (last accessed 30 March 2012)

Correspondence Address: Yvonne Galligan, School of Politics, International Studies and Philosophy, Queen's University Belfast, University Road, Belfast BT7 1NN, Northern Ireland. Email: y.galligan@qub.ac.uk.
} 
to disappear, limiting the possibilities of seat turnover and access to politics for new candidates (Hinds, 2012:108-109). Although under the UK's 2002 Sex Discrimination (Election Candidates) Act parties can introduce positive action measures to counter gender inequality in candidate selection, no party in Northern Ireland has used it as a basis for redressing gender imbalances. In the 2010 general election, Knight and Galligan (2010) found that men voted more than women in Northern Ireland: while over three in every five male voters cast their ballot (60.9 per cent), a plurality of women did so (52.3 per cent). Yet, no party in that election, or in any other post 1998 election, have sought to mobilise women citizens to vote and, as section four will show in more detail, women's policies in manifestos are heavily circumscribed.

The representational problem, on the surface, can be attributed to the scarcity of women selected by parties to run for an Assembly seat. Matthews (2012) has calculated that in the four Assembly elections from 1998 to 2011, women comprised only 17 per cent of all candidates, with the Ulster Unionist Party (UUP) and Democratic Unionist Party (DUP) being the most reluctant of the five main parties to run women candidates. This was reflected in the pattern of candidate selection for the 2011 Assembly election (see Table 1).

\section{TABLE 1 ABOUT HERE}

Thus, Northern Ireland politics is overwhelmingly male-gendered, despite the promise of women's inclusion stitched into the Agreement. Yet, there is a curious mismatch between voter and party behaviour: when women are given the opportunity of running in constituencies where their party has a prospect of winning a seat, they do just as well - if not better than - men. As Table 1 shows, male candidates had a 49 per cent chance of being elected to the Assembly, while female candidates had slightly better odds, at 53 per cent, even though they were much fewer in number. An examination of candidacy success rates also reveals party strategies in this regard: the SDLP may have fielded only four women in 2011, but managed to get three of them elected, giving a return rate of 75 per cent for women as compared to a 46 per cent return rate for SDLP male candidates.

Correspondence Address: Yvonne Galligan, School of Politics, International Studies and Philosophy, Queen's University Belfast, University Road, Belfast BT7 1NN, Northern Ireland. Email: y.galligan@qub.ac.uk. 
Other parties offering women winnable prospects were the Ulster Unionist Party (67 per cent), and Sinn Féin where the outcome for female and male candidates was equally positive, 73 per cent and 72 per cent. Surprisingly, although the cross-community Alliance Party proportionally ran more women candidates than any other party, the conversion of these candidacies into party seats was low, at 29 per cent. However, male candidates' 38 per cent return rate, though better than that of their female colleagues, was lowest of all parties and illustrates the party's quite precarious purchase on the narrow middle-ground of Northern Ireland's politics. The DUP successfully elected the party's largest number of female members MLAs (Member of Legislative Assembly), five, in 2011, marking a healthy return rate of 71 per cent for DUP women.

Thus, despite the unusually low female turnout rate in Northern Ireland as compared with Great Britain and European patterns (Campbell and Childs, 2011; Banducci, Galligan and Hayes, 2008), women candidates garnered more votes on average than male candidates at the 2011 Assembly elections. The vote dividend for female candidates from the main parties was 421 (see Table 2). Reflecting women candidates high success rate for the SDLP and UUP, their vote dividend was almost 1000 - 964 and 926 respectively. Strikingly, while the actual outcome of 5 female MLAs for the DUP was a new high in party terms, it was the only party in which men significantly outpolled women (by an average of 459 votes). This is in contrast to the other parties, where women's average vote has increased over the four elections since 1998 to outstrip that of their male running mates (see Figure 5).

\section{TABLE 2 ABOUT HERE}

\section{FIGURE 5 ABOUT HERE}

The unexpected finding of a vote bonus for female candidates in the context of a relatively conservative society can be explained, at least to some extent, by the woman-friendly orientation of 
those turning out to vote. In the 2010 UK general election in Northern Ireland ${ }^{5}$, men who indicated a greater interest in politics (and therefore most likely to vote) were more likely to support the idea of having more women in politics than men with lower levels of political interest (and so less likely to vote). Women voters, on the other hand, irrespective of their level of political interest, had a strong desire to see more women in politics, with 64 per cent of women voters expressing this view Galligan and Knight 2011: 602). The positive return rate and vote advantage conferred on women candidates in the 2011 Assembly election suggests that the voter trend in 2010 carried into the subsequent election to the devolved legislature. This finding holds a positive message to parties and women political aspirants: with the exception of DUP supporters, those citizens that take the trouble to cast their vote are favourably disposed to seeing women elected (Galligan and Knight 2011: 603). Along with the rise of interest among professional women in gender equality outcomes, this is a further signal of a general societal desire for greater gender diversity in the Assembly. This finding is stronger than the one recently obtained in experimental research conducted with British voters (Campbell and Cowley 2013), which tested the impact of a range of candidate characteristics, including sex, on voter choice. The nature of electoral contests in Northern Ireland, which are fought within two ethnic blocks (and so parties within each block need to find a way of differentiating themselves from their nearest rival) and in multi-member constituencies (which places a premium on localism), may contribute to this stronger sex finding in Northern Ireland. Given that promoting women's political equality is a visible way for a party to distinguish itself from its nearest ethnic rival, the puzzle is why parties are reluctant to put women forward for election, and timid about responding to women's policy issues. These are the concerns, in turn, of the following two sections.

\footnotetext{
${ }^{5}$ This is the only election for which this data is available, and extrapolations are made on the basis of the proximity of the 2010 general election and the 2011 Assembly election

11

Correspondence Address: Yvonne Galligan, School of Politics, International Studies and Philosophy, Queen's University Belfast, University Road, Belfast BT7 1NN, Northern Ireland. Email: y.galligan@qub.ac.uk.
} 


\section{Parties, Women, and Candidate Selection}

Parties articulate identifiable ideological and strategic policy positions in tune with the views and interests of their voters. In this regard, how parties treat women's candidacy opportunities is a good measure of a party's internal and external commitment to gender equality. Qualitative research has shown that the nationalist parties (Sinn Féin and Social Democratic and Labour Party - SDLP) indicate broadly positive support for closing the gap between women's and men's descriptive representation, as does the cross-community Alliance Party. Unionist parties, however, have not been particularly strong advocates for women's representation (Wilford and Galligan, 1999). In a qualitative study of women supporters of unionist parties, Ruth Chapman (2012: 31) reported that the lack of females in leadership roles in the unionist political community was a matter of concern for her respondents: the views of one interviewee captured the general view of women's exclusion from positions of influence and power: '[women are] always in the background and not a very noticeable one', and another noted that 'the roles [women have] tend to be behind the scenes: admin and drumming up support, running of offices'. Indeed, within all parties, women members drive the question of women's representation, including within the relatively stony soil of unionism (Ward, 2004). The fact that this has had no appreciable impact on candidate selection outcomes suggests that unionist party cultures have not yet accepted women's democratic right to equal participation.

Recent research (Matthews, 2012; Side 2009) has highlighted the attitudinal biases towards males and the reluctance of parties to see the dearth of women candidates as a structural problem rather than a problem of individual efficacy. Interestingly, Matthews (2012:8) reveals that the DUP guidelines for candidate selection provide for a sex -balanced outcome, with selection determined by merit: 
unless there are extenuating circumstances, it is not expected that any Association would nominate representatives from one gender only...[though it] should not be at the expense of the merit principle (DUP, rule 18:20).

Given the poor record of women's selection in the DUP, it is clear that the merit condition has largely privileged male aspirants. In addition, the party is on record as having actively chosen not to implement the Sex Discrimination (Election Candidates) Act believing that it implies the introduction of candidate gender quotas (Side, 2009: 78). An additional obstacle is presented by the high incumbency rate of DUP representatives, with a low turnover of party MLAs reinforcing gender inequality in the party's representative profile (Matthews, 2012:8).

Sinn Féin practices on candidate selection are more interventionist than those of the DUP: the party executive (Árd Chomhairle) ratifies candidate lists, if necessary overturning local decisions in seeking to fulfil its target of having 30 per cent of winnable seats being contested by female candidates (Matthews, 2012: 9-10; Side, 2009: 79). The outcome is evident, with women comprising a significant minority of the party's Assembly candidates with good prospects of election given their placement in winnable seats and the disciplined vote gathering and vote distribution between constituency candidates. It is the only party to specify a sex-related candidate target, though given its nationalist credentials, does not invoke the 2002 Sex Discrimination (Elections Candidates) Act in doing so.

For the SDLP, candidate selection power rests largely with the local organisation, with minimal interference from party headquarters. This process reinforces the relative autonomy of male MLAs in deciding on their running mates, and accentuates the risk-averse tendencies of local party members unwilling to break the mould of the male politician (Matthews, 2012: 10-11). Over the past five years, repeated unsuccessful efforts have been made by female party members to introduce candidate selection rules such as candidate sex-quotas that would increase women's selection opportunities. Until this happens, the see-saw pattern of women's vote bonus - high at one election, 
low at the next - will continue as women fight individualised battles for places on constituency tickets.

The UUP also has traditionally had a strongly localist selection procedure, though this changed in 2007 with the introduction of candidate shortlists, constituency primaries and a headquartersdominated election committee with a final decision on candidates. However, although a large measure of power over candidate selection has been wrested from the local association (Matthews, 2012:11-14), a more diverse and gender-balanced candidate slate has not materialised. Women continue to be chosen in token numbers, the nadir point being 2007 when the party ran only one female candidate.

Finally, the Alliance Party frontloads the involvement of the party head office in candidate selection, as it provides an 'approved' list of potential candidates to each constituency organisation from which to choose their standard-bearer (Matthews, 2012: 13-14). Although the party has eschewed introducing guidelines on candidate gender balance, the outcome has regularly delivered a significant proportion of female candidates for the party. This can be in part explained by the party's longstanding recognition of the merit of women as representative and the leading role played by successive women in representative politics for the party. ${ }^{6}$

Double and triple office-holding has also acted as a barrier for new representatives to come through, depressing opportunities for male and female aspirants alike. While a private members bill to outlaw dual mandate-holding introduced in 2010 by then-leader of the Progressive Unionist Party (PUP) and MLA, Dawn Purvis, was blocked by the DUP, the debate aired the arguments for bringing more women into political office (Hinds, 2012: 108). Subsequently, in the light of public opinion wishing to see an end to dual mandate-holding, parties voluntarily and gradually began to move to single mandates. A legislative end to the practice of 'double jobbing' by the time of the 2015 Assembly elections was included in a bill pertaining to Northern Ireland introduced to the House of Commons

\footnotetext{
${ }^{6}$ Deputy leadership positions have been held by Eileen Bell, former MLA and Naomi Long MP.

Correspondence Address: Yvonne Galligan, School of Politics, International Studies and Philosophy, Queen's University Belfast, University Road, Belfast BT7 1NN, Northern Ireland. Email: y.galligan@qub.ac.uk.
} 
on 9 May 2013, and the Minister for the Environment, Alex Attwood (SDLP) indicated an intention to introduce local legislation to ban the practice when the new local councils came into effect in 2015. While endogenous public attitudes and political events have moved the debate on the gendered imbalances in representation, so too has the contagion effect of the gender quota law in Ireland (Buckley, 2013; McGing, 2013). This has had the effect of mobilising civil society to demand political reform through the adoption of similar measures, or at least through implementation of the Sex Discrimination (Election Candidates) Act. In 2012, Minister Attwood announced his intention to explore the options regarding the introduction of gender quotas for elections to the reformed local councils, though nothing has since been heard of this initiative. The under-representation of women in devolved politics was also discussed during the 2013 Assembly and Executive Review Committee ${ }^{7}$ hearings on reviewing the functioning of these institutions. Pressure for this reform was maintained through 2013 by a loose coalition of interested feminist groups, elected representatives, organisations dedicated to improving women's political representation such as the UK 'Counting Women In' and Ireland's '5050 Group' campaigns, along with institutional equality-seeking bodies. By 2013, the issue had generated a momentum that not seen since the formation of the Northern Ireland Women's Coalition in 1996. This pressure for change rested on a confluence of public attitudes, a mobilised civil society bringing grassroots women's organisations and professional women's groups into a confident advocacy of progress, voters indicating support for female candidates, and diffusion of debates taking place elsewhere in close-by political systems. This constellation of internal and 'near neighbour' effects were reinforced in the Equality Commission shadow report on the implementation of the UN Convention on the Elimination of all forms of Discrimination Against Women (CEDAW) (ECNI, 2013: 8-9). The combined effect of these pressure

\footnotetext{
7 The Assembly and Executive Review Committee is established under the Northern Ireland Act, 1998 that gives effect to the 1998 Agreement and its subsequent modifications. It was charged with reviewing the operation of Parts III and IV of the Northern Ireland Act 1998 by Secretary of State for Northern Ireland, Owen Patterson MP, in August 2012.
}

Correspondence Address: Yvonne Galligan, School of Politics, International Studies and Philosophy, Queen's University Belfast, University Road, Belfast BT7 1NN, Northern Ireland. Email: y.galligan@qub.ac.uk. 
points has made women's descriptive representation difficult for parties to ignore, though by and large party response has been slow.

\section{Interest Aggregation and Women: Party Platforms 1998-2011}

The reluctance to recognise women's representational claims as valid is carried further in how parties recognise women's substantive interests. Since 1998, when women's contribution to bringing about the Agreement was visible and publicly recognised, organised women in civil society have cooperated to identify significant policy areas on which it is agreed that progress is required. These issues are expressed in a Women's Manifesto document presented to parties at each election as the women's agenda for change in Northern Ireland. These policies present the views of civil society women on the reforms required in the areas of childcare provision, economic independence, sexual and reproductive health, the community women's sector, education, and women and decisionmaking, to promote women's empowerment and a more gender equal society (Women's Ad-hoc Policy Group, 2011). An analysis of political party manifestos for commitments to women since the Agreement as a response to successive iterations of the Women's Manifesto charts the extent to which parties recognise and give substantive commitments on gender equality.

During the 1990s, the UUP articulated a concept of gender equality that was grounded in terms of equal opportunities in the workplace. Equal pay was an explicit goal, along with encouragement of family-friendly work practices. The party highlighted its intention to expand or develop a number of supportive policy interventions such as workplace childcare, flexible retirement and improvements in the quality of life of older women. It also addressed women's health and domestic violence issues. In terms of public life, it stated a commitment to the principle of merit, eschewing any form of positive discrimination (Wilford and Galligan, 1999: 174-5). This liberal-oriented agenda continued into the 2000 's, although internal pressure sought a more pro-active recruitment and development programme for women members (Ward, 2004: 7). By 2011, and with the party's youngest and most 
recent leader at the helm ${ }^{8}$, this modest approach to gender equality was still in evidence: the gender pay gap, equality in the workplace, implementing a childcare strategy, supporting women in circumstances of domestic violence and outlawing trafficking were key policy commitments (WRDA, 2011). The manifesto stated that the UUP 'want to create opportunities for women of all ages, providing them with genuine choices, empowering each to reach their full potential and to further maximise their contribution to society' (UUP, 2011: 33). Yet the manifesto was silent on the matter of women in public life, even though the party had taken renewed internal action to encourage women's political participation from the mid 2000's. In all, UUP policies on gender equality are constructed on classical liberal equal opportunity lines and indicate a cautiously reforming response to successive Women's Manifestos.

The DUP manifestos generally ignored women's representation and issues until recently, emphasising constitutional matters above all others. Such was the tone of the 1997 manifesto, in which the only reference to women was in the female sexing of Ulster: 'Ulster faces a crisis never before encountered in her history' - a common gendering of the nation that has real-life impacts on the role and status of women. The party however referenced the roles of women through their mothering duties. Reluctantly accepting women's workplace participation as a non-reversible pattern of modern life, it advocated flexible working arrangements for mothers to enable them reconcile their caring duties with employment (Wilford and Galligan, 1999: 175-176). Women were also cast as victims of male aberrant behaviour, requiring protection from perpetrators of domestic violence and rapists, reinforcing a view of women's dependence on male protectors in more trenchant language than that employed by the UUP. Even the content of a glossy 2003 manifesto containing images of women on the cover made no policy reference to gender equality, instead stating that 'the rights of women are adequately dealt with under the ECHR', though the party 'actively promotes legislative measures to eliminate domestic violence directed at women' (Ward,

\footnotetext{
${ }^{8}$ Tom Elliott replaced Sir Reg Empey as leader in 2010.
}

Correspondence Address: Yvonne Galligan, School of Politics, International Studies and Philosophy, Queen's University Belfast, University Road, Belfast BT7 1NN, Northern Ireland. Email: y.galligan@qub.ac.uk. 
2004: 7). The 2011 DUP manifesto managed to avoid using the term 'women' altogether, preferring the occasional use of the more remote word 'female'. It reiterated two commitments to women in keeping with its conservative outlook on reproductive rights and protectionist view of women - to oppose the introduction of the 1967 Abortion Act to Northern Ireland, and to assist survivors of domestic abuse to remain safely in their homes. The party framed gender equality in terms of children's rights (with no gender distinctions) teen pregnancy reduction, and father's rights within the family. It sought to dismantle the institutional arrangements for equality and human rights, thereby signalling an intention to undermine recognition of gender equality and of women as a political category. In 2010, the party's general election manifesto incorporated a view on women's representation in line with its candidate selection policy: the DUP 'wished' to see more women in political life, but only through adherence to the principle of merit. The 2011 manifesto did not address this issue, although the party has initiated internal attention to women's representation, championed by Arlene Foster, who had a track record of advocating for more women in political life during her membership of the UUP. Over a fifteen year period, then, DUP manifestos score low in responsiveness to the range of issues raised in successive Women's Manifestos.

The SDLP, with an active women's group, has had the benefit of drawing on detailed feministoriented policy research and analysis for inclusion in party manifestos. This is evident from 1997, when the party endorsed the need for 'affirmative action to allow women equality of opportunity in the job market', promised to bring in a single equality bill, and linked its pro-woman health policies with wider international agendas including that of the 1995 UN Platform for Action. It also acknowledged the impact of the conflict, and a militarised society, on women's lives through the need for concerted action to tackle domestic violence which the party acknowledged was a sideeffect of a communal desensitisation to violence (a contextual analysis absent from UUP and DUP manifestos) (Wilford and Galligan, 1999: 178-179). Similar issues are raised in the party's 2003 Assembly manifesto, though specific references to women, and gender equality, are minimal. By Queen's University Belfast, University Road, Belfast BT7 1NN, Northern Ireland. Email: y.galligan@qub.ac.uk. 
2011 it seemed that the influence of feminist members on party policy had waned. It advocated fewer measures than before to provide for gender equality, and paid almost as much attention to children's issues without explaining how addressing these concerns would empower women as mothers. Moreover, the party also found it necessary to state that men's issues and needs required inclusion in governmental gender action plans. Women's political representation, long a concern of the active women's group, was a party ambition in 1999, and in the intervening years the party pursued an active agenda in this regard with considerable success. From 2003, when the manifesto was silent on women's representation, the issue was neglected and its advocates sidelined within the party. The 2011 manifesto returned to this matter, offering an internal review of how best to encourage women in public and political decision-making - picking up the threads of the 1990s achievements. Successive manifestos, then, indicate a less feminist drift in party thinking on gender equality, and while the 2011 document spoke to some measures in the Women's Manifesto in terms compatible with the civil society document, the fit was not as comfortable as before.

The small cross-community Alliance Party has had a record of explicitly addressing women's political under-representation from 1997 onwards through positive soft equal opportunity measures such as encouragement and training. It too, from this time, adhered to the merit principle as a means of organising the distribution of political power, befitting of its liberal orientation. By 2011, it had become stronger in its endorsement of women's rights, explicitly linking these to international obligations, including CEDAW. It also recognised the importance of women's contribution in sustaining peace through support for implementation of UN Security Council Resolution 1325 (see Hoewer, 2013). In particular, it endorsed 'measures to ensure women's equal access to and full participation in power structures and decision-making' (quoted in WRDA, 2011: 2). Among an extensive range of policies directed to supporting gender equality, it advocated statutory funding for women's leadership in society, an integrated strategy on violence against women, a comprehensive expansion of educational opportunities, the development of the social economy, and gender 
mainstreaming of welfare reforms. Over time, the Alliance Party has indicated an increasing support for women's empowerment, and these issues have occupied an ever-growing space in the party's policy agenda. In contrast to other parties, its 2011 manifesto related in a positive and direct way to the interests expressed in the Women's Manifesto, marking an increase in party attention to gender equality issues and compatible with its ambitions to represent cross-community, non-sectarian and inclusive politics.

Sinn Féin has benefited from a pro-active, research-focussed women's section that has enabled the party to articulate a coherent and comprehensive gender equality agenda within a Republican framework. Its 1997 general election manifesto and subsequent local election manifesto identified a number of policy areas in which it sought to address women's 'systematic and institutionalised sexual discrimination' - including equal pay, educational reform, combating sexism, eradicating violence against women, a responsive strategy for rape victims, and statutory funding for community-based women's organisations (Wilford and Galligan, 1999: 179). It also paid attention to women's representation, and in the 1998 manifesto advocated 'measures to achieve equality of representation both in political life and in appointments to all public bodies' without stating what these measures should be. The party's 1999 extensive policy document on women clarified this point, with gender mainstreaming, target-setting and monitoring progress towards achieving 50:50 representation within Sinn Féin structures (Ward, 2004:10). A 50:50 gender quota applied to membership of the party's national executive (Ard Chomhairle) from 2003 (Side, 2009: XX). The 2011 Assembly manifesto addressed a range of key areas in gender equality terms, including a focus on maternal health and reproductive care, increasing women's recruitment to the police service through reinstatement of the 50:50 community-based recruitment quota and its application to women, opposition to welfare cuts, an all-Ireland charter of rights, protecting childcare and education and addressing violence against women (Sinn Féin, 2011[Cc1]; WRDA, 2011: 5-6). Gender proofing and gender mainstreaming were identified once again as procedures to ensure the 
integration of women's interests in policy-making. Although the general manifesto and the women's manifesto for south Belfast did not directly map on to the Women's Manifesto, many of the issues were common to both documents and the overall equality-seeking objectives were shared concerns. Over time, then, Sinn Féin has displayed a sustained commitment to gender equality, and to gender proofing and mainstreaming all policies. It arguably has developed and expressed the most sophisticated appreciation of the complex relationship between women, gender equality, and public policy of all parties in Northern Ireland. It has framed this analysis, and political commitment, in an ethno-national rhetoric, as part of an all-Ireland equality agenda.

Overall, and over time since the 1998 Agreement, party responses to women's policy concerns as expressed in the Women's Manifesto have varied. In particular, the written commitment to women's equal participation in political and public life contained in the Good Friday-Belfast Agreement has largely been ignored until recently by unionist parties, consistently promoted as part of a nationalist equality agenda by Sinn Fein, regularly acknowledged as challenge for democratic politics by Alliance, and subject to variable attention by the SDLP.

In responding to other substantive equality-seeking policy reforms sought by Women's Manifestos, the parties have responded according to their orientation on equality issues: the UUP and SDLP sharing a classical liberal equal opportunities view, Sinn Fein articulating a strongly comprehensive approach to tackling gender inequality within a republican ideology, and the DUP offering a limited, protectionist view along traditional gender role lines. The parties that have shown most movement on women's descriptive representation are the SDLP and Alliance: the SDLP shifting towards a more conservative position on women's policy matters, the Alliance becoming more confident in its woman-friendly imprint. The other parties have maintained their stances, with minor modifications. In addition to being revealing of the cultural perception of women as a policy focus, the responses closely mapped onto party engagement with women's representation as shown through candidate selection practices. Commitment in one area broadly correlated with commitment in the other. 


\section{Discussion and Conclusion: Gender justice and gender politics in Northern Ireland}

This article takes the view that delivering gender justice in politics strengthens democracy through making it more diverse in representation and more responsive to women in society. This normative view is brought to bear on Northern Ireland's politics since the signing of the Good Friday-Belfast Agreement in 1998, evaluating how far politics seeks to deliver on gender justice. The previous sections have sought to identify the empirical evidence for progress in delivering on the promise of equal rights to political participation and representation in the Agreement. This section discusses the evidence using the four criteria for evaluating gender justice - inclusion, transparency, accountability and recognition.

If one takes the equal right to political participation in the Agreement as a standard to which to aspire, it is clear that women's inclusion in representative politics falls far short of this ambition. As gatekeepers to representative politics, some parties have facilitated women's descriptive representation by different means. While voter preferences show no bias against women candidates, and indeed statistical analysis conducted elsewhere indicates positive voter support for seeing more women in politics (with the single exception of DUP supporters), no party has equal inclusion of women as candidates with men for either local government or Assembly office. While candidate selection rules and procedures have become increasingly transparent to outsiders since 1998, inhibitors to women's selection remain within the parties. These obstacles could be interpreted as an artefact of women's ambition. Indeed the robust and often sectarian nature of politics in Northern Ireland can be off-putting to all but political die-hards. Yet, women's ambition is not constrained in other fields of economic and professional life, and the dearth of women at the pinnacle of these areas suggests that the cultural climate of Northern Ireland remains conservative on gender equality matters. Indeed, the fact that with the exception of the Alliance Party and Sinn Fein, parties in general have not felt it necessary to be accountable to women in civil society, or 
indeed to their own supporters, for women's low representation suggests a cultural bias favouring men, and male-defined interests.

These observations point to the weak recognition of women's right to equal descriptive and substantive representation. Indeed, the general withholding of this recognition takes different forms: as an explicit feature of electoral politics, and in the context of policy reform and development. All parties have indicated resistance to the adoption of sex quotas for candidate selection, though Sinn Fein seeks to enforce targets. Contained in policy terms as domestic abuse and equal pay, unionist parties have seldom taken cognisance of the gendered nature of public policy in key areas presented in successive Women's Manifestos. Two parties do respond to a wider gender equality agenda, Alliance and Sinn Fein, from different ideological standpoints, while over time the SDLP has become less ambitious in this regard.

There is no doubt that moving from an 'armed patriarchy' to secular pluralist politics takes time. But in the fifteen years since the Agreement, there is scarce evidence that such a politics offers recognition to women and women's political interests. Parties' aggregation of women's interests is confined to statements on a limited range of relatively non-contentious issues. Women's reproductive rights are ignored in manifestos, while strongly challenged in political debate. Parties equivocate between offering to ameliorate the worst manifestations of unequal gender power relations - such as being relatively responsive to addressing domestic abuse and trafficking issues and lapsing into a reification of family in which women's traditional role is indirectly affirmed. The relatively tokenist presence of women as empowered political agents makes it difficult for women within parties to challenge this culture - especially as they risk losing their positions by going against party policy.

Gender justice, then, is far from being realised in Northern Ireland. The culture of politics is resistant to including, recognising and being accountable to women in an open and transparent manner. As the politics of normal democracy has taken hold, pressure for party action on women's descriptive Queen's University Belfast, University Road, Belfast BT7 1NN, Northern Ireland. Email: y.galligan@qub.ac.uk. 
representation has become the lightening rod for civil society women frustrated at the continued non-responsiveness of the political system to their consensus interests. As a relatively conventional culture and practice of politics embeds in Northern Ireland, women's expectations of equality, descriptive and substantive, have grown. The politics of Northern Ireland are set to be influenced by gender justice issues for some time to come.

\section{References}

ARK (1998) Northern Ireland Assembly Elections, available at http://www.ark.ac.uk/elections/98eb.htm (accessed 19 June 2013)

ARK (2003) Northern Ireland Assembly Elections, available at http://www.ark.ac.uk/elections/ (accessed 19 June 2013)

Banducci, S. Galligan, Y. and Hayes, B. (2008) More Women Candidates Mean More Female Voters, PS Public Service, available at http://www.publicservice.co.uk (accessed 12 May 2013)

Buckley, F (2013) Women and Politics in Ireland: the Road to Gender Quotas, Irish Political Studies, $28(3), \mathrm{pp}$.

Campbell, R and Cowley, P. (2013) What Voters Want: Reactions to candidate characteristics in a survey experiment, Political Studies, doi: 10.1111/1467-9248.12048

Cave, S. (2012) Local government reform past and present, Paper NIAR 463-12, (Belfast: Northern Ireland Assembly)

CAWP (Centre for Advancement of Women in Politics) and Rachel McConville (2012) Women in the Northern Ireland Assembly available at www.qub.ac.uk/cawp (accessed 19 June 2013)

Chapman, $R$ (2012) Women's place within the unionist community: 100 years from the Covenant, Thesis submitted in partial fulfilment of an MA in Gender and Society, Queen's University Belfast.

Campbell, R. and Childs, S. (2011). 'Wags', 'Wives', and 'Mothers'...but what about Women Politicians? In A. Geddes and J. Tonge (Eds.), Britain Votes 2010, Oxford: Oxford University Press.

Coakley, J. (2012) Nationalism, ethnicity and the State: making and breaking nations, (London: Sage)

Cowell-Meyers, K (2011) 'Social movements into political parties: how the women's movement in Northern Ireland used the strategy of a political party to gain access', paper presented at ECPR Annual Conference, Reykjavik, Iceland, 25 August 2011

Deiana, M. (2013) Women's Citizenship in Northern Ireland after the 1998 Agreement, Irish Political Studies, $28(3)$, pp.

DUP (Democratic Unionist Party) (2011) Lets Keep Northern Ireland moving forward, (Belfast: DUP)

Correspondence Address: Yvonne Galligan, School of Politics, International Studies and Philosophy, Queen's University Belfast, University Road, Belfast BT7 1NN, Northern Ireland. Email: y.galligan@qub.ac.uk. 
DETI (Department of Enterprise, Trade and Investment) (2004) Northern Ireland labour force survey: Women in Northern Ireland, July 2004, (Belfast: DETI)

DETI (Department of Enterprise, Trade and Investment) (2005) Women in Northern Ireland, February 2005, (Newport: National Statistics)

DETI (Department of Enterprise, Trade and Investment) (2006) Women in Northern Ireland, (Newport: National Statistics)

DETI (Department of Enterprise, Trade and Investment) (2007) Norther Ireland Labour Force Survey: Historical supplement Spring 1984-Spring 2006, (Newport: National Statistics)

DETI (Department of Enterprise, Trade and Investment) (2009) Women in Northern Ireland, September 2009, (Newport: National Statistics)

DETI (Department of Enterprise, Trade and Investment) (2010) Women in Northern Ireland, September 2010, (Newport: National Statistics)

DFP (Department of Finance and Personnel) (2012) Review of Gender in the Northern Ireland Civil Service, (Belfast: DFP)

The Electoral Commission (2007) (2011) Elections to the Northern Ireland Assembly 2007, 2011 available at http://www.electoralcommission.org.uk/elections/results/devolved legislatures (accessed 19 June 2013)

Electoral Reform Society, Scully, R. and Gareth, O. (2011) The 2011 Welsh Assembly Election In depth, available at www.electoral-reform.org (accessed 12 May 2013)

ECNI (Equality Commission for Northern Ireland) (2013) Shadow report to the Committee on the Elimination of Discrimination Against Women, (Belfast: ECNI)

European Commission (2013) Database: Women and Men in Decision-making, available at http://ec.europa.eu/justice/gender-equality (accessed 5 June 2013)

Fearon, K (2000) Whatever happened to the women? Gender and peace in Northern Ireland. In M. Cox, A. Guelke and F. Stephen (Eds.) A farewell to arms?: From 'long war' to long peace in Northern Ireland, pp. 153-164, (Manchester: Manchester University Press)

Feenan, D. (2005) Applications by Women for Silk and Judicial Office in Northern Ireland, Belfast: Commissioner for Judicial Appointments for Northern Ireland.

Fraser, $N$ (1998) Social justice in the age of identity politics: redistribution, recognition and participation. In G.B. Peterson (Ed.) The Tanner Lectures on Human Values: Volume 19, pp. 167, Utah: Utah University Press.

Galligan, Y. and Clavero, S. (2008) Assessing gender democracy in the European Union: A methodological framework, RECON online working paper 2008/16. Available at www.reconproject.eu (accessed March 2012).

Correspondence Address: Yvonne Galligan, School of Politics, International Studies and Philosophy, Queen's University Belfast, University Road, Belfast BT7 1NN, Northern Ireland. Email: y.galligan@qub.ac.uk. 
Galligan, Y. and Knight, K. (2011) Attitudes towards women in politics: gender, generation and party identification in Ireland, Parliamentary Affairs 64:4, 585-611

Hayes, B. C. and McAllister, I. (2013) Gender and consociational powersharing in Northern Ireland, International Political Science Review 34:2, pp. 123-139

Hillyard, P. McWilliams, M. and Ward, M. (2006) Northern Ireland Gender Audit, (Belfast: Economic and Social Research Council)

Hinds, B. (2012) Women's political participation. In McGrattan, C. and Meehan, E. (Eds.) Everyday life after the Irish conflict: the impact of devolution and cross-border co-operation, pp. 98-114, (Manchester: Manchester University Press)

Hinds, B. and Grey, A. M. (2005) Women and the Review of Public Administration, (Belfast: The Review of Public Administration in Northern Ireland)

Hoewer, M. (2013) UN Resolution 1325 in Ireland: Implications for women's rights, Irish Political Studies, 28 (3), pp.

Knight, K. and Galligan, Y. (2010) Gender gaps in the 2010 General Election: A Research Note, paper presented at Governance and Public Policy seminar, Queen's University Belfast, 13 October 2010

Matthews, N. (2012) 'Gendered candidate selection and the representation of women in Northern Ireland, Parliamentary Affairs online, doi: 10.1093/pa/gss079

McGing, C. (2013) The Single Transferable Vote (STV) and Women's Representation in Ireland, Irish Political Studies, 28 (3), pp.

McMillan, J. and Fox, R. (2010) Has Devolution Delivered for Women? (London and Edinburgh: Hansard Society and British Council Scotland)

McMinn, K. (2011) The Long and Winding Road: The political marginalisation of women in the development of sustainable peace in post-conflict societies, Dissertation submitted in partial requirements for the Degree of Master of Arts in Peace and Conflict Studies, University of Ulster, April 2011

Meehan, E. and MacKay, F. (2013) A 'new politics' of participation? In McGrattan, C. and Meehan, E. (Eds.) Everyday life after the Irish conflict: the impact of devolution and cross-border cooperation, pp. 169-183, (Manchester: Manchester University Press)

Moller-Okin, S. (1999) Is Multiculturalism Bad for Women?, Princeton: Princeton University Press.

Morrow, D. (2012) The rocky road from enmity. In McGrattan, C. and Meehan, E. (Eds.) Everyday life after the Irish conflict: the impact of devolution and cross-border co-operation, pp. 20-36, (Manchester: Manchester University Press)

Murtagh, C. (2008) A Transient Transition: The Cultural and Institutional Obstacles Impeding the Northern Ireland Women's Coalition in its progress from Informal to Formal Politics, Irish Political Studies 23:1, pp. 21-40

Correspondence Address: Yvonne Galligan, School of Politics, International Studies and Philosophy, Queen's University Belfast, University Road, Belfast BT7 1NN, Northern Ireland. Email: y.galligan@qub.ac.uk. 
Northern Ireland Assembly (2002) Public appointments and public bodies in Northern Ireland, Research Paper 04/02, (Belfast: NIA)

NIJAC (Northern Ireland Judicial Appointments Commission) (2013) Annual Report and Accounts 2005-2006, Belfast: NIJAC

NISRA (Northern Ireland Statistical Research Agency) (2012) The Judiciary in Northern Ireland: 2012 Equity Monitoring Report, (Belfast: NISRA)

O'Keeffe, T. (2012) 'Sometimes it would be nice to be a man': negotiating gender identities after the Good Friday Agreement. In McGrattan, C. and Meehan, E. (Eds.) Everyday life after the Irish conflict: the impact of devolution and cross-border co-operation, pp. 83-97, (Manchester: Manchester University Press)

O'Leary, B. (1999) The nature of the Agreement, Fordham Journal of International Law 22:4, pp. 1628-1667

OFMDFM (Office of First Minister and Deputy First Minister) (2010) Public Bodies and Public Appointments Annual Report 2009-10, (Belfast: OFMDFM)

OFMDFM (Office of First Minister and Deputy First Minister) and McDowell, P. (2010a) The Gender Pay Gap in Context: Causes, consequences and international perspectives, (Belfast: OFMDFM)

OFMDFM (Office of First Minister and Deputy First Minister) (2012) Public Bodies Annual Report 2011-12, (Belfast: OFMDFM)

Porter, E. (1998) Political representation of women in Northern Ireland, Politics 18:1, pp. 25-32

Potter, M. (2012) Loyalism, Women and Standpoint theory, Irish Political Studies DOI: 10.1080/07907184.2012.727399

Prenzler, T. and Sinclair, G. (2013) The status of women police officers: an international review, International Journal of Law, Crime and Justice, pp. 1-17 [in press]

Side, K. (2009) Women's civil and political citizenship in the post-Good Friday Agreement period in Northern Ireland, Irish Political Studies 24:1, pp. 67-88

Sinn Féin (2011) Leadership Across Ireland: Sinn Fein Assembly Election Manifesto 2011, Belfast: Sinn Fein

SDLP (Social Democratic and Labour Party) (2003) Reshaping Government, Rebuilding Public Services, (Belfast: SDLP)

UUP (Ulster Unionist Party) (2011) Its time to make Stormont work - for you: manifesto 2011. (Belfast: UUP)

Correspondence Address: Yvonne Galligan, School of Politics, International Studies and Philosophy, Queen's University Belfast, University Road, Belfast BT7 1NN, Northern Ireland. Email: y.galligan@qub.ac.uk. 
Ward, R. (2004) Gender issues and the representation of women in Northern Ireland, Irish Political Studies, 19:2, pp. 1-20

Wilford, R. and Galligan, Y. (1999) Gender and party politics in Northern Ireland. In Y. Galligan, E. Ward and R. Wilford (Eds.), Contesting Politics: Women in Ireland, North and South, pp. 169184, (Boulder, CO: Westview Press and PSAI Press)

WRDA (Women's Resource and Development Agency) (2005) Submission to the Review of Public Administration in Northern Ireland, Belfast: WRDA

Women's ad hoc Policy Group (2011) The Women's Manifesto - NI Assembly and Local Government Elections 2011, (Belfast: WRDA)

WRDA (Women's Resource and Development Agency) and Hinds, B. (2011) The Northern Ireland Economy - Women on the Edge: a comprehensive analysis of the impacts of the financial crisis, (Belfast: WRDA)

WRDA (Women's Resource and Development Agency) (2011) Northern Ireland Assembly and Local Government Election 2011: Commitments to Women (and other relevant issues) in Political Party Manifestos, (Belfast : WRDA)

Young, I.M. (2002) Inclusion and Democracy, Oxford: Oxford University Press

Correspondence Address: Yvonne Galligan, School of Politics, International Studies and Philosophy, Queen's University Belfast, University Road, Belfast BT7 1NN, Northern Ireland. Email: y.galligan@qub.ac.uk. 
Tables and Figures

Figure 1: Devolution and women's representation

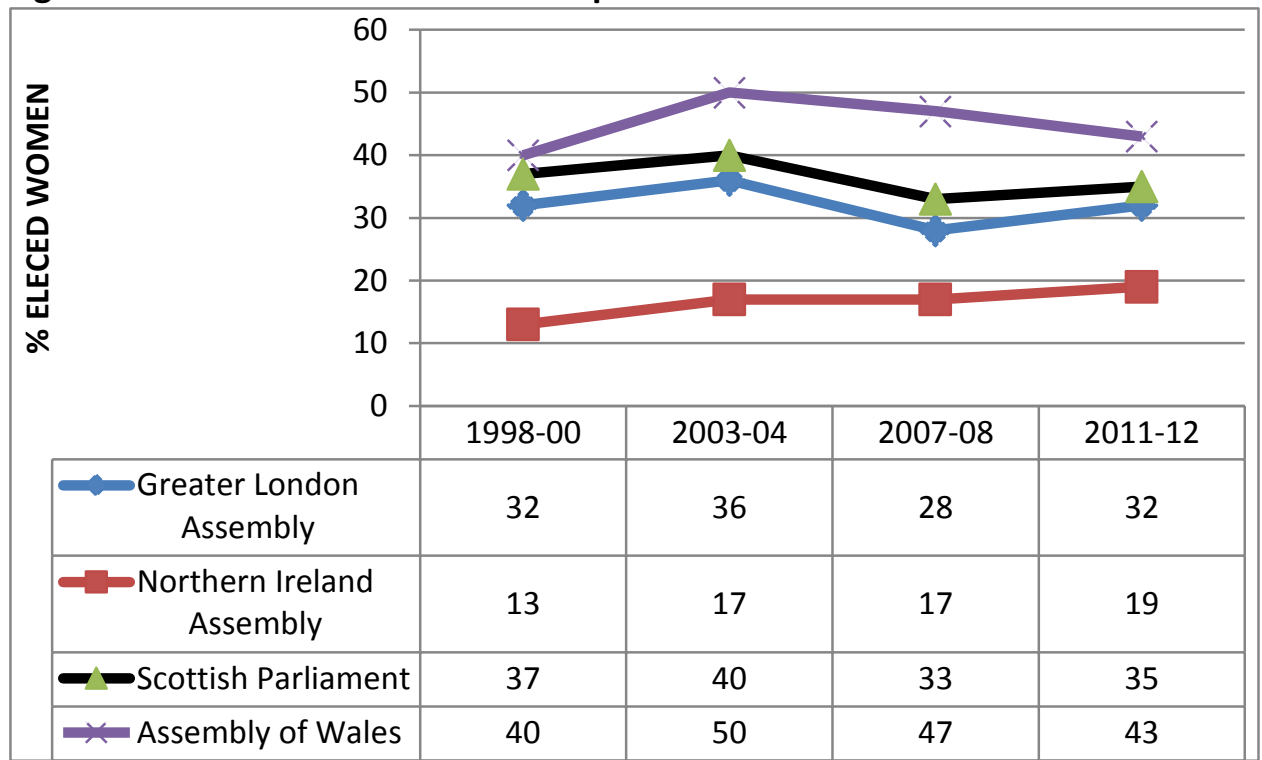

Source: Websites of devolved assemblies (accessed 1 June 201

Figure 2: Women in Local Councils, Northern Ireland, 1989-2011

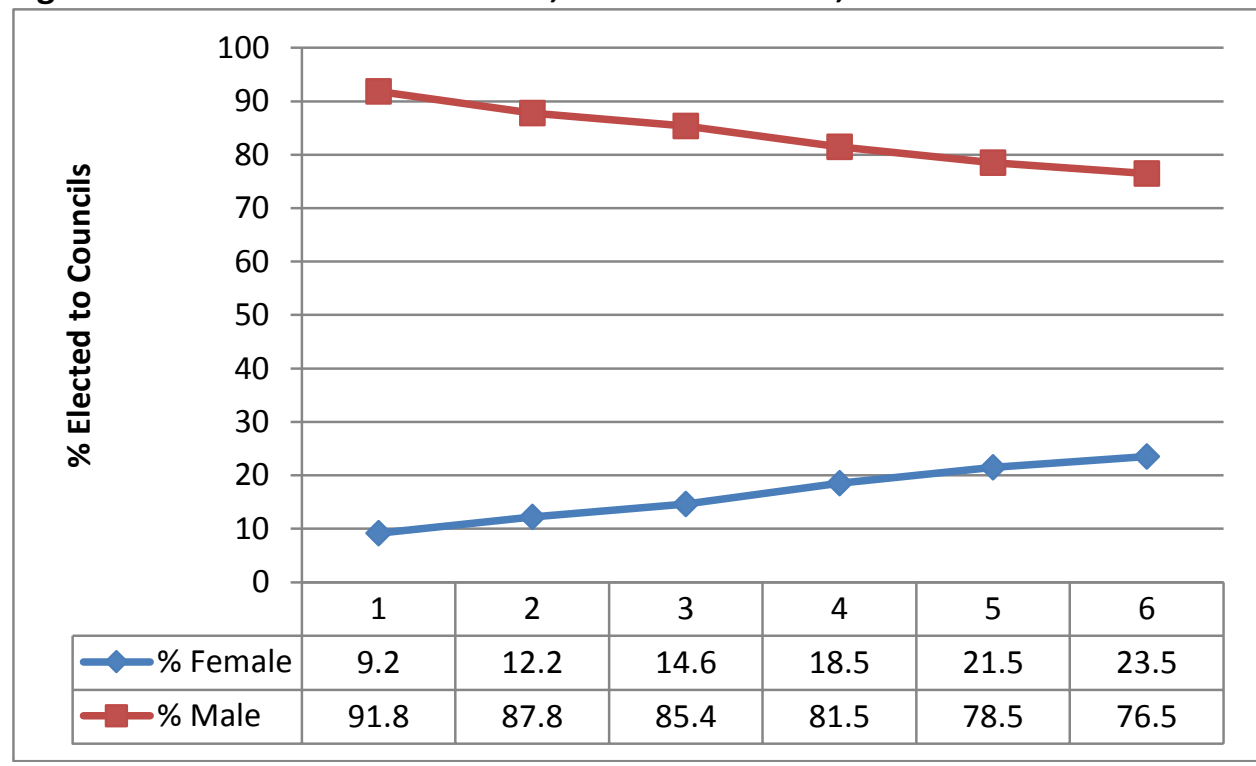

Sources: CAWP, Electoral Office for Northern Ireland, DFPNI 2012, Hillyard et al (2006)

Correspondence Address: Yvonne Galligan, School of Politics, International Studies and Philosophy, Queen's University Belfast, University Road, Belfast BT7 1NN, Northern Ireland. Email: y.galligan@qub.ac.uk. 
Figure 3: Employment rates for women and men in Northern Ireland (\%), 1995-2013

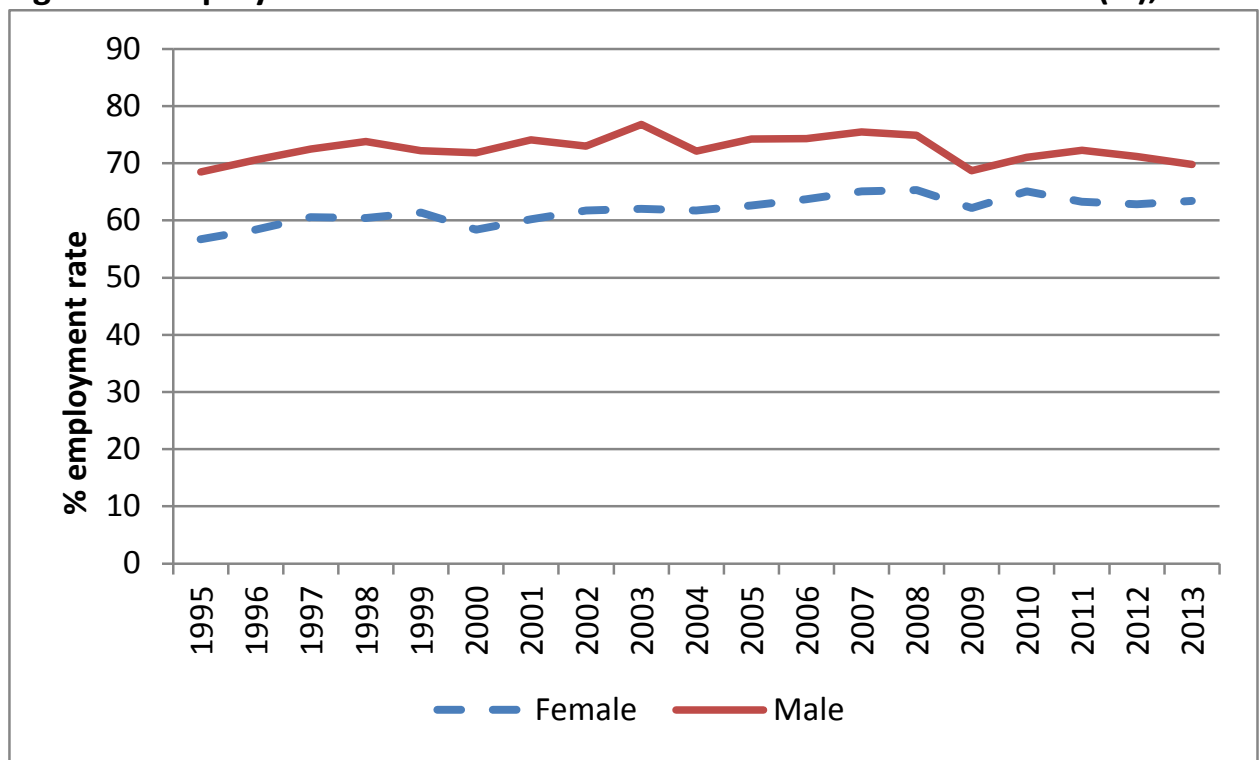

Source: 1995-2005 figures are drawn from NI Labour Force Survey Historical Supplement 2006; 2006-2012 figures are drawn from annual Women in NI reports, DETI.

Figure 4: Average vote difference between female and male candidates at NI Assembly elections 1998-2011

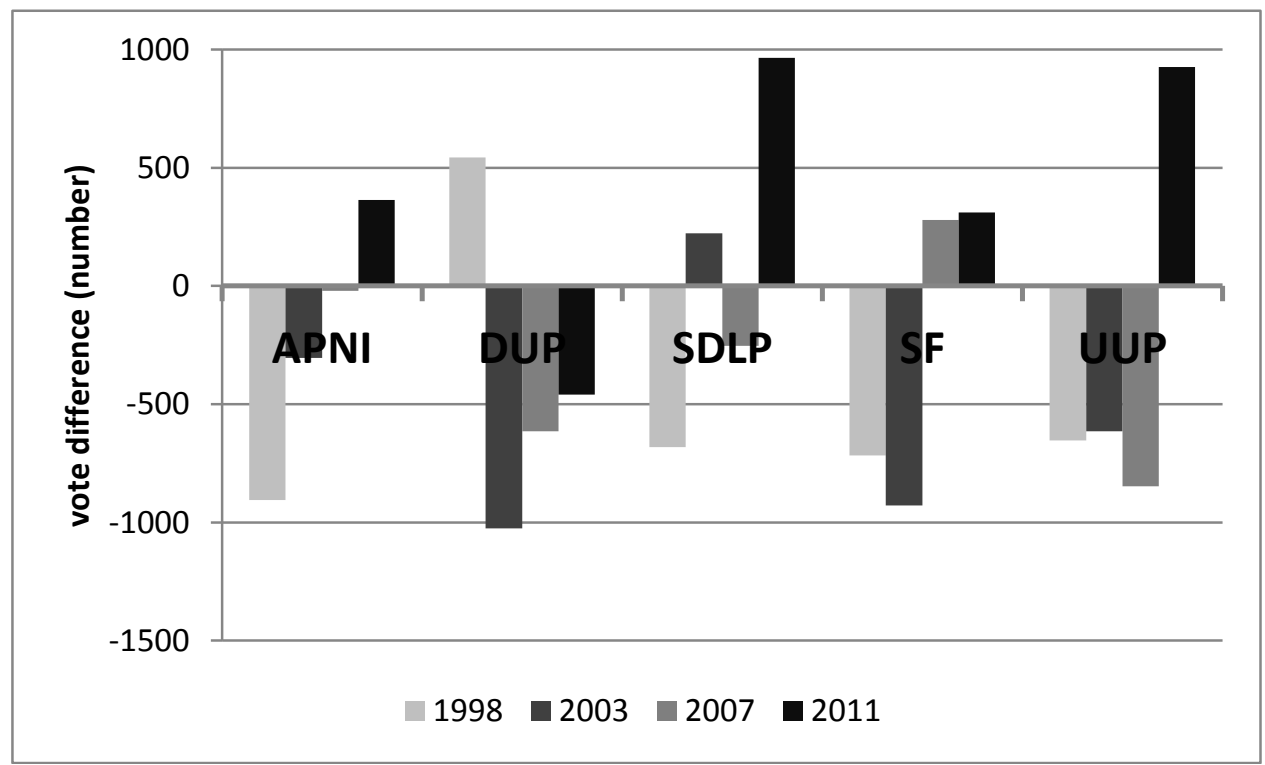

Note: Bars below the 0 axis indicates that male candidates garnered more votes on average than female candidates.

Source: 1998, 2003 ARK elections archive; 2003, CAIN elections archive, 2007 and 2011 Electoral Office of Northern Ireland

Correspondence Address: Yvonne Galligan, School of Politics, International Studies and Philosophy, Queen's University Belfast, University Road, Belfast BT7 1NN, Northern Ireland. Email: y.galligan@qub.ac.uk. 
Table 1: Candidates and MLAs in the 2011 Election to the Northern Ireland Assembly, by sex

\begin{tabular}{|c|c|c|c|c|c|c|}
\hline \multirow[t]{2}{*}{ Party } & \multicolumn{2}{|c|}{ Candidates } & \multicolumn{2}{|c|}{ MLAs } & \multirow{2}{*}{$\begin{array}{c}\text { Female } \\
\text { Rate of } \\
\text { Return } \\
\text { (\%) }\end{array}$} & \multirow{2}{*}{$\begin{array}{c}\text { Male } \\
\text { Rate of } \\
\text { Return } \\
\text { (\%) }\end{array}$} \\
\hline & $\begin{array}{c}\text { Female } \\
\text { N (\%) }\end{array}$ & $\begin{array}{l}\text { Male } \\
\text { N (\%) }\end{array}$ & $\begin{array}{c}\text { Female } \\
\text { N (\%) }\end{array}$ & $\begin{array}{l}\text { Male } \\
\text { N (\%) }\end{array}$ & & \\
\hline Alliance & 7 (30) & $16(70)$ & 2 (25) & $6(75)$ & 29 & 38 \\
\hline DUP & 7 (16) & 37 (84) & $5(13)$ & $33(87)$ & 71 & 89 \\
\hline SDLP & 4 (14) & $24(86)$ & $3(21)$ & 11 (79) & 75 & 46 \\
\hline SF & $11(28)$ & $29(72)$ & $8(28)$ & 21 (72) & 73 & 72 \\
\hline UUP & $3(10)$ & $26(90)$ & 2 (13) & $14(87)$ & 67 & 54 \\
\hline Other & 6 (11) & 49 (89) & 0 & 3 (100) & 0 & 100 \\
\hline Total & 38 (17) & 181 (83) & 20 (19) & 88 (81) & 53 & 49 \\
\hline
\end{tabular}

Source: CAWP briefing Women in the NI Assembly,2012.

Table 2: Average candidate votes in 2011 Assembly election, by sex

\begin{tabular}{|l|c|c|c|}
\hline Party & Male & Female & $\begin{array}{l}\text { Average } \\
\text { Difference }\end{array}$ \\
\hline Alliance & & & \\
\hline DUP & 2197 & 2560 & 363 \\
\hline SDLP & 4664 & 4205 & -459 \\
\hline SF & 3205 & 4169 & 964 \\
\hline UUP & 4370 & 4681 & 311 \\
\hline Average & 2953 & 3879 & 926 \\
\hline
\end{tabular}

Note: a negative (-) sign indicates that male candidates from that party received more average votes than that of female candidates from the same party.

Source: author calculations from Electoral Commission 2011 data 